\title{
Título da página electrónica: Newtopia Magazine
}

Endereço: http://www.newtopiamagazine.net

\section{Rui Bebiano}

\section{(2) OpenEdition \\ Journals}

Edição electrónica

URL: http://journals.openedition.org/rccs/1173

DOI: $10.4000 /$ rccs. 1173

ISSN: 2182-7435

\section{Editora}

Centro de Estudos Sociais da Universidade de Coimbra

\section{Edição impressa}

Data de publição: 1 outubro 2003

Paginação: 195

ISSN: 0254-1106

\section{Refêrencia eletrónica}

Rui Bebiano, "Título da página electrónica: Newtopia Magazine », Revista Crítica de Ciências Sociais [Online], 66 | 2003, posto online no dia 01 outubro 2012, consultado o 22 setembro 2020. URL : http:// journals.openedition.org/rccs/1173; DOI : https://doi.org/10.4000/rccs.1173 


\section{Espaço Virtual}

\section{Título da página electrónica: The Hacktivist: Hacktivism \& Technopolitics Endereço: http://thehacktivist.com}

The Hacktivist move-se dentro de uma área que se encontra nas mãos de internautas com tempo disponível para se ocuparem diariamente com um dos lados mais absorventes, mas também menos conhecidos, do ciberespaço. A página dedica-se ao exame da teoria e da prática do hacktivismo. Isto é, à interpretação e à legitimação dos processos que permitam furar a segurança dos sistemas de comunicação em rede. Ocupase igualmente com a observação participada da desobediência civil por via electrónica, através de um debate construtivo, de uma acção directa efectiva, e da procura criativa de soluções que permitam resolver os problemas complexos que nesse domínio a todo o momento se colocam. As escolhas são diversas, mas os temas e a linguagem não ocultam sinais comuns: navega-se aqui dentro de um universo essencialmente juvenil, que procura debater, com um elevado grau de optimismo e um agudo sentido de oportunidade, as formas de resistência à intervenção das novíssimas máquinas censurantes. Por sua vez, alguns dos links incluídos remetem ainda para artigos colocados em outros servidores, numa lógica hipertextual que reforça a intenção de ampliar o debate acerca da intensa dimensão política que a rede possui neste momento. Ou daquela que pode vir a deter num futuro que os responsáveis por The Hacktivist acreditam não se encontrar distante.

\section{Título da página electrónica: Newtopia Magazine Endereço: http://www.newtopiamagazine.net}

A palavra que domina este espaço é: novo. É pois na busca de novos processos de compreensão e de representação do mundo, que esta revista electrónica americana funda a sua actividade em linha. Pode ler-se de três maneiras diferentes, mas aqui que se revelam complementares. Como publicação voltada para temas de natureza sociológica e cultural, procurando examinar de que forma a política e as políticas se podem ver reflectidas em áreas tão diversas como as práticas de governo, as formas de produção artística e as experiências ocorridas na área das humanidades. Depois como espaço experimental para o lançamento de debates que, seguindo processos não convencionais, visam promover o intercâmbio entre diferentes formas de opinião e de análise. E finalmente enquanto área de expres- são de possibilidades inexploradas: teorias e propostas em condições de poderem desenhar novas utopias projectadas para novas realidades, funcionando também como alimento dinamizador dentro do actual processo de crescimento e renovação dos grandes movimentos sociais. Newtopia é tudo isso e ainda algo mais: uma superfície virtual, ao dispor da reabilitação do debate político e da reformulação de projectos, que fala sobretudo para a "geração-Internet" - como chamou Bernard Préel aos cidadãos que se tornaram adolescentes ao longo dos anos 90 -, recusando, com um notável esforço de fundamentação e ainda um grande vigor, as formas de populismo que a todo o momento a procuram atrair.

\section{Rui Bebiano}

